\title{
MATERNITY ROOST SELECTION BY FRINGED MYOTIS IN COLORADO
}

\author{
Mark A. Hayes ${ }^{1,2}$ and Rick A. Adams ${ }^{1}$
}

\begin{abstract}
AвstRaCT.-Fringed myotis (Myotis thysanodes) is a bat species of conservation concern in western North America that may be impacted by increased recreational activity near roost sites, changes in water resource availability caused by increased urban and agricultural water use, and anthropogenic climate change. Our purpose was to describe and model maternity roost use by fringed myotis in Colorado. We compared differences between roosts occupied by maternal fringed myotis and randomly selected potential roosting locations that were not known to be occupied by this species during the maternity period. We evaluated the strength of evidence for competing hypotheses on 2 scales: one that included landscape variables and a second that included roost-site variables. We used logistic regression, Akaike's information criterion, and multimodel inference to investigate maternity roost use by fringed myotis. The model explaining the most variability in our landscape data included grade and aspect, and the model explaining the most variability in our roost-site data was estimated volume of the roost. Understanding maternity roost use by fringed myotis can guide conservation and management decisions related to roost protection in the Rocky Mountain West. When feasible, we believe that developing knowledge about maternity roost use, as well as autumn and winter roost use, will help improve management decision making related to forest bats of conservation concern in western North America.
\end{abstract}

Resumen.-Myotis thysanodes es un murciélago del oeste de Norte América en peligro, posiblemente debido al aumento de la actividad humana cerca de sus refugios, los cambios en la disponibilidad de recursos hídricos causados por el aumento del uso urbano y agrícola del agua, y el cambio climático antropogénico. Nuestro propósito fue describir y modelar el refugio materno de $M$. thysanodes en Colorado. Comparamos las diferencias entre los refugios ocupados para maternidad por M. thysanodes y los refugios potenciales seleccionados al azar que no sabíamos si estaban o no ocupados por esta especie durante el período de maternidad. Evaluamos la fuerza de la evidencia que comparaba dos escalas de hipótesis: una que incluía variables del paisaje y la segunda que incluía las variables del refugio. Utilizamos una regresión logística, el criterio de información de Akaike, y la inferencia multi-modelo para explorar el uso del refugio para maternidad por $M$. thysanodes. El modelo que explicó la mayor variabilidad en nuestros datos de paisaje incluyó el grado y el aspecto, y el modelo que explicó la mayor variabilidad en nuestros datos de refugios estimó el volumen del refugio. Entender el uso del refugio para maternidad por M. thysanodes puede ayudar a guiar las decisiones de conservación y de gestión relacionadas con la protección de los refugios en el Oeste de las Montañas Rocosas. Cuando sea posible, creemos que aumentar el conocimiento sobre el uso de refugios para maternidad, así como el uso de refugios durante el otoño e invierno, ayudar a mejorar la gestión y la toma de decisiones relacionadas con la conservación de los murciélagos forestales en el oeste de América del Norte.

Fringed myotis (Myotis thysanodes) is a bat species of conservation concern in western North America (Adams 2003, O'Shea et al. 2003). In 1994, fringed myotis was designated as a Category 2 candidate species for listing under the United States Endangered Species Act (USFWS 1994), and since 1996 when the Category 2 Endangered Species Act designation was eliminated fringed myotis has been considered a "species of concern" in the western United States (USFWS 1996, O’Shea et al. 2003). Concern about this species led the Western Bat Working Group to designate fringed myotis as "high" or "medium" conservation priority in all ecoregions of western North America (Western Bat Working Group
1998). The United States Forest Service lists fringed myotis as a "sensitive species" in the Rocky Mountain Region (USDA Forest Service 2006). In Colorado, fringed myotis is listed as a mammal species of "greatest conservation concern" and is considered as having low population status, with unknown population trends (CDOW 2005).

Fringed myotis is known to roost in buildings (O'Farrell and Studier 1980), caves and mines (O'Farrell and Studier 1980, Navo et al. 1991, Navo 2001, Navo and Krabacher 2005), tree snags (Rabe et al. 1998, Cryan et al. 2001, Weller and Zabel 2001, Chung-MacCoubrey 2003, 2005), and rock crevices (Bogan et al. 1998, Cryan et al. 2001, Lacki and Baker 2007).

\footnotetext{
${ }^{1}$ School of Biological Sciences, University of Northern Colorado, Greeley, CO 80639

${ }^{2}$ Present address: Cherokee Services Group, LLC (CSG), Contractor to DOI-United States Geological Survey, Fort Collins Science Center, 2150 Centre Avenue, Building C, Fort Collins, CO 80526. E- mail: hayesm@usgs.gov
} 
Maternity roosts, where reproductive females give birth to and raise young to volancy, are found in a variety of substrates. Studier (1968) and Findley et al. (1975) reported maternity colonies using attics of buildings that were not occupied by humans. Dalquest et al. (1990) reported finding a maternity colony of 300 females and young-of-the-year in an abandoned copper mine at the base of Black Mesa, which straddles the Colorado-New MexicoOklahoma tristate border. Weller and Zabel (2001) found that maternity colonies in northern California switched roosts frequently, were generally located in Douglas-fir (Pseudotsuga menziesii) snags that on average had diameters larger than random snags, and were in forest stands with larger numbers of snags than random stands. Cryan et al. (2001) found maternity colonies in the Black Hills of South Dakota using both ponderosa snags (Pinus ponderosa) and rock crevices, with the majority of maternity roosts located in rock crevices. In mixed conifer forests in New Mexico, Bogan et al. (1998) found maternity colonies in rock crevices high on cliff walls. Along the Colorado Front Range, fringed myotis maternity colonies have been identified in rock crevices, and radio-tracking of females of this species found that maternity colonies occurred only in rock features (see Hayes 2011 for a list of documented fringed myotis roosts in Colorado).

The Colorado Front Range is an area of rapid urbanization (Grimm et al. 2008), resulting in environmental modifications and habitat fragmentation (Magle et al. 2009), and is home to known fringed myotis populations. Rapid urbanization has occurred from Pueblo to Fort Collins, with the most expansive growth and development around Denver. The geographic and elevational distribution of fringed myotis overlaps with urban areas along the Front Range (Hayes and Adams 2014). Because the geographic distribution of fringed myotis coincides with this band of urbanization, this species may be impacted by human activities, including increased recreational activity near roost sites and changes in water resource availability caused by increased urban and agricultural water use (Adams and Hayes 2008, Hayes and Adams 2014). Furthermore, there has been increased concern regarding the impacts of anthropogenic and climate changes on water resources (Arnell 2004, Christensen and Lettenmaier 2006,
Björk and Molau 2007, Kang and Ramírez 2007, Ray et al. 2008, Saunders et al. 2008, Auble et al. 2009), as well as the impact of reductions in surface water availability, on bats in the Southern Rocky Mountains (Adams and Hayes 2008, Adams 2010). Anthropogenic changes along the Front Range could also affect the availability of suitable maternity roosts for fringed myotis. Increasing urbanization has resulted in habitat disturbance, including exploration of abandoned mines and recreational rock climbing, which may deter use of these structures as roosts. Deforestation in the late 1800s and early 1900s, forest habitat fragmentation, forest diseases (e.g., mountain pine beetle), certain forest management practices (e.g., removal of snags and ongoing forest thinning to reduce wood fuel), might have also impacted maternity roost site availability. Further, long-term regional climate change could significantly impact the distribution of maternity roost availability by altering microclimates within traditionally used roost sites (Hayes 2011).

Wildlife managers, researchers, and conservation biologists have emphasized the need for detailed information about roost use by fringed myotis in the Southern Rocky Mountains region. For example, the Colorado Bat Conservation Plan (Ellison et al. 2003) used a conservation priority score to rank Colorado species. In this plan, fringed myotis received the second-highest conservation priority score of all Colorado bat species, with a highlighted need for information concerning roost preferences. Our purpose was to describe and model maternity roost use by fringed myotis in Colorado. We compared differences between roosts occupied by maternal fringed myotis and randomly selected potential roosts that were not occupied by this species during the maternity period. We hypothesized that the landscape variables elevation, grade (slope), aspect, and proximity to permanent water influenced fringed myotis maternity roost selection. We also hypothesized that the roost-site variables mean temperature, mean relative humidity during the maternity season, and estimated volume of the roost influenced maternity roost selection. We use logistic regression within a maximum likelihood framework and multimodel inference (Burnham and Anderson 2002) to evaluate the strength of evidence for each hypothesis. We then consider 
how this information can improve our understanding of maternity roost selection by fringed myotis in Colorado, and elsewhere in western North America.

\section{METHODS \\ Study Area}

The study area was within the known range of fringed myotis in Colorado (Armstrong et al. 1994, Adams 2003, Armstrong et al. 2011). Fieldwork during this project emphasized Colorado Front Range locations in Boulder and Larimer Counties that were $<3000 \mathrm{~m}$ in elevation. This area of the Front Range consists primarily of Douglas-fir (Pseudotsuga menziesii) and ponderosa pine (Pinus ponderosa) forests, meadows, montane shrublands, and grasslands and is at the transition zone between the Colorado Piedmont section of the Great Plains physiographic province and the Southern Rocky Mountains (Chapman et al. 2006).

\section{Data Collection}

All available information on roost locations of fringed myotis in Colorado was compiled. This information was obtained from Colorado Division of Wildlife documents and databases, museum records, primary literature, and the reports, field notes, and records of mammalogists, researchers, and others who have conducted bat survey work in Colorado. This information included fringed myotis records from the Colorado Bats/Inactive Mines Project, whose personnel have conducted over 3200 internal and capture surveys at abandoned mines throughout Colorado since 1991 (K. Navo personal communication). In an effort to discover additional fringed myotis maternity roosts in Boulder and Larimer Counties, Colorado, we conducted mist-netting in areas likely to be visited by bats. This consisted of placing mist nets over or near water, trails, roads, forest edges, and meadows. Once bats were captured, standard data were gathered including species, age class (Brunet-Rossinni and Wilkinson 2009), and reproductive status (Racey 2009). Radio-transmitters (Holohil Systems Ltd., Carp, Ontario, Canada; LB-2N, weight 0.36 g, 12-day battery life) and temperature-sensitive radiotransmitters (Holohil Systems Ltd., Carp, Ontario, Canada; LB-2NT, weight 0.38 g, 12-day battery life at $40{ }^{\circ} \mathrm{C}$, with temperature calibrated signal) were used. To facilitate discovery of fringed myotis maternity roost sites, we preferentially radio-tagged females of reproductive age and attempted to track them to roost sites (Amelon et al. 2009). We followed the $5 \%$ rule when applying radio-tags, such that the tag weighed $\leq 5 \%$ of the body weight of the bat (Aldridge et al. 1988, Neubaum et al. 2005). We radio-tagged lactating and postlactating females, but did not tag pregnant females. Radio-tags were attached to parted fur and skin between the scapulae by use of waterproof Perma-Type surgical cement (The Perma-Type Company Inc., Plainsville, CT). Once a bat was radio-tagged, we initially searched for the bat near the capture location and then drove along nearby roads, using a whip antenna mounted to the roof of our field vehicle. Once a signal was located, we tracked bats on foot using handheld receivers and antennas (TRX-48S Receiver, Wildlife Materials Inc., Murphysboro, IL). We did not attempt to track bats from fixed-wing aircraft. We did not include all known fringed myotis maternity sites in Colorado in this analysis. Known maternity roost sites were selected for inclusion in this study based primarily on knowledge of the roost's exact location and safe accessibility. One known roost site (Der Zerkle in Boulder County) has been used as a maternity site for a number of years, but the exact roost crevice is not known and the rock face is difficult to access safely. Similarly, we know there is a maternity site associated with a rock outcrop in Geer Canyon (Heil Valley Ranch, Boulder County), but repeated radio-tracking efforts have failed to identify the exact location. Thus, these sites were not included in this analysis. Roost sites that are known to be occupied by other bat species were considered not to be occupied by fringed myotis if this species was not captured or observed after repeated capture and/or visual surveys.

We followed the guidelines of the American Society of Mammalogists (Sikes et al. 2011) and Colorado Division of Wildlife collection permits when capturing and handling live bats. All research was conducted after protocol review and approval by the Institutional Animal Care and Use Committee of University of Northern Colorado (permit number 0706).

Newly identified fringed myotis roosts were photographed, characterized, and added to a database of known roosts of fringed myotis in Colorado. The following information was 
recorded at each occupied maternity roost and at 2 randomly selected potential roost sites per occupied maternity roost (see below): presence of fringed myotis or other bats at the site; number of fringed myotis and whether they were roosting singly or in groups; roost substrate (rock crevice, tree snag, bridge, cave, mine, etc.); elevation; approximate internal dimensions of the roost; height of the roost off the ground, if applicable; tree trunk diameter at breast height $(\mathrm{DBH})$ if the roost was in a tree snag; approximate dimensions of the rock feature if the roost was within a rock crevice; canopy cover; and slope and aspect of the substrate. Habitat type, dominant vegetation, and distance to nearest water near the roost were also measured and recorded. Climate variables were estimated for each site using historical climate data from weather stations in the study area (Western Regional Climate Center 2010). We recorded the location of each roost in UTM coordinates (North American Datum 1927) using a Garmin eTrex GPS unit (Olathe, KS). Temperature and relative humidity data loggers (iButton Hygrochron DS-1923-FS temperature and relative humidity data loggers, Embedded Data Systems, Lawrenceburg, KY) were installed in known maternity roost sites and randomly selected unoccupied sites to gather roost-site temperature and humidity data, as described below; these sites were presumed to be unoccupied by fringed myotis based on a lack of visual evidence of this species.

\section{Analysis of Landscape and Roost Site Variables}

Potential maternity roost sites are often clustered on the landscape (e.g., in rocky areas with potential rock crevice roosts or within forested areas with tree snags), and it would be helpful if biologists and managers could prioritize potential roosts within and among clusters of potential roosting habitat. We therefore developed 2 balanced model sets: one that included landscape variables and a second that included roost-site variables. We developed 15 landscape models using 4 landscape variables that we concluded might influence roost selection (Hayes 2011). The variables used in the landscape analysis were elevation (m), grade (or percent slope) of the landscape on which the roost or randomly selected plot was located, transformed aspect of the roost (unitless variable); and proximity to a permanent water source $(\mathrm{m})$ (Table 1 ). We assumed that elevation, aspect, and slope might influence the thermal conditions inside potential roost sites, which might influence the selection of roosts by reproductive females. We also assumed that proximity to water might influence roost selection (Adams and Hayes 2008). The transformed aspect is

$$
A_{t}=\sin (\text { aspect } / 114.59) \text {, }
$$

where aspect is in compass degrees $\left(1-360^{\circ}\right)$, and 114.59 is the diametian number, which is $360^{\circ} / \pi$. This transformation converts each degree to a number between 0 and 1 , with $1^{\circ}$ and $360^{\circ}$ both close to $0(\sim 0.009)$, and $180^{\circ}$ equal to 1.000. This transformation creates an index of aspect where south-facing slopes receive a high score and north-facing slopes receive a low score. For this landscape analysis, we used data from known fringed myotis maternity roosts, and 100 randomly selected points located within the known range of fringed myotis along the Front Range in Boulder and Larimer Counties, Colorado; this number of random points was used to provide reasonable coverage of the landscape conditions available to fringed myotis along the Front Range.

We developed a roost-site model set to provide information about characteristics of roost sites that might influence maternity roost selection by fringed myotis. Such information might help identify suitable maternity roost sites within a cluster of possible roosting options. This analysis of roost-site variables used a final set of 7 candidate models using the 3 variables that we predicted most strongly influence roost selection at the roost scale; these prediction were based on the roost-selection literature (e.g., Hayes 2011) and our experience and observations in our study area. The variables used in the roost-site analysis included average temperature $\left({ }^{\circ} \mathrm{C}\right)$ inside the roost during the maternity period, relative humidity (\%) inside the roost during the maternity period, and estimated roost volume $\left(\mathrm{m}^{3}\right)$ (Table 1$)$. We assumed that roost temperature, humidity, and size might influence conditions inside potential roost sites, which in turn might influence selection of roosts by reproductive females. For this roostsite analysis, we used data from 9 known 
TABLE 1. Landscape and roost-site variables used in modeling maternity roost selection by fringed myotis (Myotis thysanodes) along the Front Range, Colorado. Landscape data were collected at maternity roosts and randomly selected potential roost sites (9 maternity roosts and 100 randomly selected potential roosts). Roost-site data were collected at maternity roosts and randomly selected potential roost sites (9 maternity roosts and 18 randomly selected potential roosts).

\begin{tabular}{lcc}
\hline & Type of variable & Unit \\
\hline Landscape variables & & $\mathrm{m}$ \\
Elevation & Continuous & $\%$ \\
Grade (slope) & Continuous & Unitless \\
Aspect $\left(A_{t}\right)$ & Continuous & $\mathrm{m}$ \\
Proximity to water & Continuous & \\
Roost-site variables & & $\mathrm{C}$ \\
Mean temperature & Continuous & $\% \mathrm{RH}$ \\
Mean relative humidity & Continuous & $\mathrm{m}^{3}$ \\
Estimated roost volume & Continuous & \\
\hline
\end{tabular}

fringed myotis maternity roosts in Colorado, including 1 roost in New Mexico that is within 5 miles of the Colorado state line. The roostsite comparison was conducted comparing variables associated with known fringed myotis roosts to variables associated with 2 randomly selected unoccupied potential roosts per known maternity roost. Thus, there were 9 known maternity roosts and 2 randomly selected potential roosts per known roost $(n=$ 27). Randomly selected potential roosts were identified by selecting random points within a $4-\mathrm{km}$ radius of the capture location. In our study area, fringed myotis have been observed traveling up to $2.8 \mathrm{~km}$ between capture locations and day roosts (Adams and Hayes unpublished radio-telemetry data). The rationale for using a $4-\mathrm{km}$ radius is that such an area circumscribes a reasonable sample of potential roosting options for the bats in a given maternity colony. These random points were each defined by first randomly selecting a number between 0 and 360. This number was used as a compass bearing expressed in degrees. A second random number was selected between 0 and 4000. This number indicated the radius in meters from the known maternity roost. The compass and measurement tool in Delorme Topo USA 5.0 mapping software (Delorme, Yarmounth, ME) and a GPS unit were used to identify the randomly selected point described by these 2 numbers. At each randomly selected point, the nearest potential rock crevice/rock debris or tree snag/loose bark roost was identified and used as a potential, but unoccupied, roost. The decision about which type of roost to select was made by flipping a coin once the first randomly selected point had been located on foot. Each potential unoccupied roost was inspected visually for bats and/or guano to confirm that the location was not currently occupied by bats. If there was no tree snag or tree with loose or peeling bark near the random point, a rock crevice/rock debris site was chosen; likewise, if no potential rock crevice/rock debris roost site was near the random point, a tree snag or loose bark roost was chosen. In 2 cases a randomly selected point was near a road bridge. In these cases, crevices in the bridge were used as potential roost locations. Hygrochon temperature and humidity iButton data loggers (DS1923-F5, Dallas Semiconductor, Sunnyvale, CA) were installed in the known maternity roost sites and randomly selected unoccupied sites for at least 4 weeks during the maternity season, from 1 June to 15 August. These data loggers sampled roost-site temperature $\left({ }^{\circ} \mathrm{C}\right)$ and humidity $(\% \mathrm{RH})$ data every 120 min during deployment. This sampling interval allowed storage of up to 170 days of data for the roost-site analysis. Temperature and relative humidity data were downloaded in the field directly from the data loggers to a laptop computer using a USB to 1-wire/ iButton Adaptor (DS9490R/DS9490B, Dallas Semiconductor, Sunnyvale, CA). Data were accessed and viewed using iButton Viewer/ 1-Wire Viewer Software (SW-DVB, Dallas Semiconductor, Sunnyvale, CA). Temperature and relative humidity data were collected at each site during the maternity periods of 2009 and 2010. We chose predictor variables for the landscape and roost-site analysis that were not collinear and were not highly correlated (e.g., Pearson correlation coefficient > $0.70)$. Use of collinear data can complicate the interpretation of the influence of each predictor variable used in a regression model (Cade 2015). 
Data related to some variables, such as diameter of tree snags and canopy cover, were excluded from final data analysis because it became clear during preliminary fieldwork that there were no meaningful relationships between these variables in the maternity roost and randomly selected potential roost data. We did not find any maternity roosts located in tree snags and concluded that the availability of tree snags in our study area (including height, diameter, canopy cover, and decay class of individual snags) was not a significant variable in determining location of maternity roosts. Likewise, given that roosts were often found in abandoned mines, in prominent rock faces unshaded by trees, and in an abandoned cabin, we concluded that canopy cover was not likely a significant variable in determining location of roosts in this data set.

We developed final sets of candidate models that were balanced model sets, such that each variable appeared in the same number of models (Burnham and Anderson 2002). By using a balanced model set, we were able to perform model selection, determine model selection uncertainty, and estimate the relative importance of each variable. We used logistic regression (Keating and Cherry 2004) and an information-theoretic approach to evaluate and guide inferences from the set of candidate models. An information-theoretic approach is useful because it allows the comparison of multiple hypotheses simultaneously (Burnham and Anderson 2002). This approach has been used successfully to identify important bat roost-site variables in other projects (Weller and Zabel 2001, Hayes 2011). We analyzed data using logistic regression and the logit link function (MiniTab, Inc., State College, PA). We assessed the global model's fit using the Hosmer-Lemeshow chi-square goodnessof-fit test (Burnham and Anderson 2002). We calculated a variation inflation factor $(\hat{c})$ for the global model to determine whether data were overdispersed (Burnham and Anderson 2002). We compared models using Akaike's information criterion for small sample sizes $\left(\mathrm{AIC}_{c}\right)$ (Burnham and Anderson 2002). We ranked models using $\mathrm{AIC}_{c}$ weights $\left(w_{i}\right)$, and a cumulative $\mathrm{AIC}_{c}$ weight $\left(w_{+}\right)$was calculated for each predictor variable. We then calculated unconditional parameter estimates $(\widetilde{\bar{\beta}})$ and $95 \%$ confidence intervals for the regression coefficient for each model variable. We considered variables with a $95 \%$ confidence interval around $\widetilde{\bar{\beta}}$ that did not overlap 0 to have a stronger effect (Burnham and Anderson 2002).

\section{Results}

Fourteen fringed myotis maternity sites were identified in or near Colorado, including 10 maternity roosts along the Front Range in Boulder and Larimer counties (Table 2). Of 12 transmitters used to track female fringed myotis, 7 bats were successfully tracked to maternity roosts, and of these, 5 bats stayed in the same roost location until the transmitter battery failed. Of the 2 females that moved, each moved only once to a nearby roost within a 500-m radius of the original roost. See Hayes (2011) for details of these results. The mean, standard error, and associated $95 \%$ confidence intervals for the landscape variables (elevation, grade, transformed aspect, and proximity to water) at fringed myotis maternity roosts and randomly selected potential roost sites are shown in Table 3.

The chi-square goodness-of-fit test suggested that data adequately fit the landscape global model (Hosmer-Lemeshow $\chi^{2}=1.363$, df $=$ $8, P=0.995)$. The estimated variation inflation factor $(\hat{c}=0.17)$ suggested data were not overdispersed (Burnham and Anderson 2002). The model that incorporated grade and transformed aspect had the most support $(\mathrm{G}+\mathrm{A}$; $w_{i}=0.43$ ) (Table 4 ). The next most parsimonious model was one that incorporated elevation, grade, and transformed aspect $(\mathrm{E}+\mathrm{G}+$ $\left.\mathrm{A} ; w_{i}=0.23\right)$. The third most parsimonious model utilized grade, transformed aspect, and proximity to water $\left(\mathrm{G}+\mathrm{A}+\mathrm{W} ; w_{i}=0.16\right)$. The second and third best models are both within $2 \mathrm{AIC}_{c}$ points of the best model and are therefore considered to be competing models, given this data set. Grade received the highest cumulative $\mathrm{AIC}_{c}$ weight $\left(w_{+}=\right.$ $1.00)$, followed by transformed aspect $\left(w_{+}\right.$ $=0.89)$, elevation $\left(w_{+}=0.37\right)$, and proximity to water $\left(w_{+}=0.27\right)$ (Table 5). Unconditional parameter estimates $(\widetilde{\bar{\beta}})$, unconditional standard errors, and associated 95\% confidence intervals for each model variable are shown in Table 6 . The $95 \%$ confidence interval for the unconditional parameter estimates for grade did not overlap 0 (0.0840-0.0952), and this variable is considered to have stronger support, 


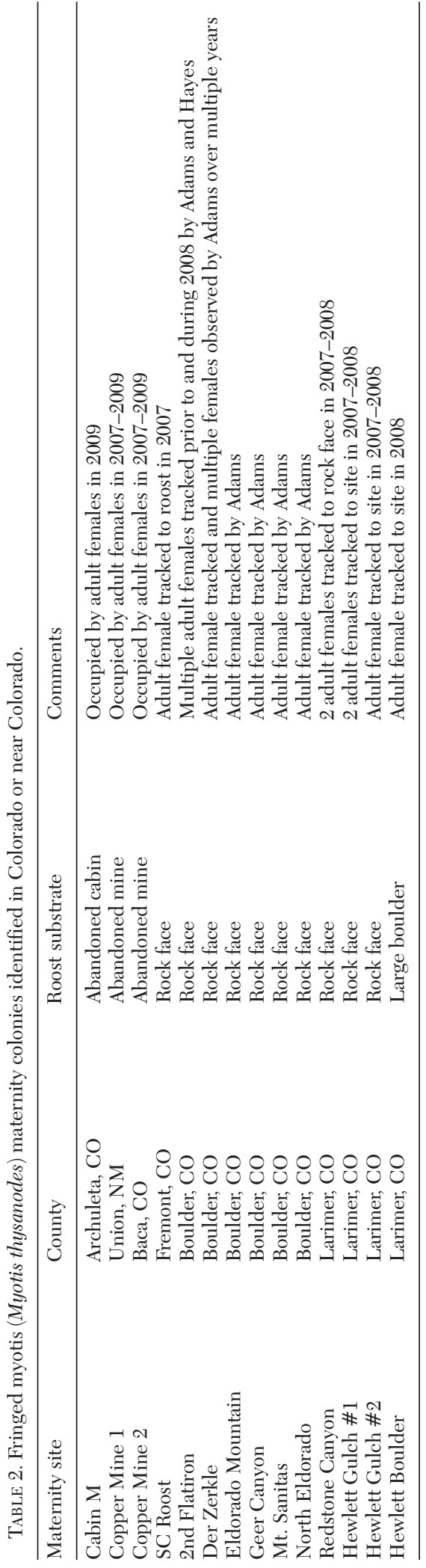

given this data set. The $95 \%$ confidence interval for the unconditional parameter estimate transformed aspect also did not overlap 0 (4.6508-11.1891) and is considered to have stronger support, given this data set.

Nine maternity roosts ( 2 abandoned mines, 1 abandoned cabin, and 6 rock faces) and 18 randomly selected potential roosts $(9$ rock faces, 8 tree snags, and 1 bridge) were used in the roost-site analysis. The chi-square goodness-of-fit test for the roost-site analysis suggested that the data adequately fit the landscape global model (Hosmer-Lemeshow $\chi^{2}=$ $6.176, \mathrm{df}=8, P=0.627)$. The estimated variation inflation factor $(\hat{c}=0.77)$ suggested data were not overdispersed (Burnham and Anderson 2002). The model that estimated volume of the structure had the most support $\left(w_{i}=\right.$ 0.30) (Table 7). The next most parsimonious models incorporated temperature and relative humidity inside the structure $\left(w_{i}=0.26\right)$ and temperature inside the structure and the estimated volume of the structure $\left(w_{i}=0.23\right)$. Estimated roost volume received the highest cumulative $\mathrm{AIC}_{c}$ weight $\left(w_{+}=0.74\right)$, followed by average roost temperature $\left(w_{+}=\right.$ $0.56)$, and relative humidity $\left(w_{+}=0.47\right)$ (Table $5)$. Unconditional parameter estimates $(\widetilde{\bar{\beta}})$, unconditional standard errors, and associated 95\% confidence intervals for each model variable are shown in Table 7 . The 95\% confidence intervals for the unconditional parameter estimates for average roost temperature, relative humidity, and estimated roost volume all overlapped 0 ; therefore, these variables are not considered to have stronger support, given this data set.

\section{Discussion}

We documented reproductive female fringed myotis using a variety of roosting resources as maternity sites, including abandoned mines, cabins, and rock structures. However, in Colorado we did not document maternity colonies of fringed myotis using trees or tree snags. All lactating or postlactating female fringed myotis that were captured and radiotracked to roost sites were roosting in crevices in rock structures, and all but one of these rock features were large structures on the landscape. For example, female fringed myotis were tracked to large rock faces in the Cache la Poudre canyon and to flatirons and similar 
TABLE 3. Landscape variables used in modeling of maternity roost selection by fringed myotis (Myotis thysanodes) along the Front Range in Boulder and Larimer Counties, Colorado. Landscape data were collected at maternity roosts and randomly selected potential roost sites (9 maternity roosts and 100 randomly selected points). Variables at randomly selected points and maternity roosts are shown as the mean $(\bar{x})$ and associated $95 \%$ confidence interval (CI). Roost-site data were collected at maternity roosts and randomly selected potential roost sites ( 9 maternity roosts and 18 randomly selected potential roosts). Temp $\left({ }^{\circ} \mathrm{C}\right)$ is mean temperature and Humidity $(\% \mathrm{RH})$ is mean relative humidity.

\begin{tabular}{|c|c|c|c|c|}
\hline & \multicolumn{2}{|c|}{ Potential roosts } & \multicolumn{2}{|c|}{ Maternity roosts } \\
\hline & $\bar{x}$ & $95 \% \mathrm{CI}$ & $\bar{x}$ & $95 \% \mathrm{CI}$ \\
\hline \multicolumn{5}{|l|}{ Landscape variables } \\
\hline Elevation $(\mathrm{m})$ & 3750 & $3456-4064$ & 3880 & $3631-4129$ \\
\hline Grade $(\%)$ & 11.32 & $8.48-14.16$ & 43.22 & $32.61-53.58$ \\
\hline Aspect & 0.69 & $0.64-0.74$ & 0.93 & $0.86-0.99$ \\
\hline Proximity to water (m) & 988 & $744-1202$ & 546 & $274-817$ \\
\hline \multicolumn{5}{|l|}{ Roost-site variables } \\
\hline Temp $\left({ }^{\circ} \mathrm{C}\right)$ & 20.0 & $17.5-22.5$ & 20.9 & $18.6-23.3$ \\
\hline Humidity (\%RH) & 62.6 & $23.5-101.7$ & 60.1 & $22.8-97.3$ \\
\hline Roost volume $\left(\mathrm{m}^{3}\right)$ & 4.3 & $0-12.5$ & 785.4 & 0-1805 \\
\hline
\end{tabular}

TABLE 4. Log-likelihood, number of parameters $(K)$, Akaike's information criterion adjusted for small sample size $\left(\mathrm{AIC}_{c}\right), \mathrm{AIC}_{c}$ difference $\left(\Delta_{i}\right)$, and $\mathrm{AIC}_{c}$ weight $\left(w_{i}\right)$ for each landscape model used in the balanced model comparison using data collected at 109 sites (9 fringed myotis [Myotis thysanodes] maternity sites and 100 randomly selected points). $\mathrm{E}=$ elevation, $\mathrm{G}=$ grade, $\mathrm{A}=$ transformed aspect, $\mathrm{W}=$ proximity to water. The model $\mathrm{E}+\mathrm{G}+\mathrm{A}+\mathrm{W}$, for example, includes all 4 variables: elevation, grade, transformed aspect, and proximity to water. Higher $\mathrm{AIC}_{c}$ weights $\left(w_{i}\right)$ indicate more support for the model, given the variables and data used. Models are listed by $\mathrm{AIC}_{c}$ weight.

\begin{tabular}{|c|c|c|c|c|c|}
\hline Model & Log likelihood & $K$ & $\mathrm{AIC}_{c}$ & $\Delta_{i}$ & $w_{i}$ \\
\hline $\mathrm{G}+\mathrm{A}$ & -16.026 & 3 & 38.28 & 0.00 & 0.43 \\
\hline$E+G+A$ & -15.575 & 4 & 39.59 & 1.25 & 0.23 \\
\hline $\mathrm{G}+\mathrm{A}+\mathrm{W}$ & -15.940 & 4 & 40.26 & 1.98 & 0.16 \\
\hline $\mathrm{E}+\mathrm{G}+\mathrm{A}+\mathrm{W}$ & -15.510 & 5 & 41.60 & 3.23 & 0.08 \\
\hline $\mathrm{E}+\mathrm{G}$ & -18.232 & 3 & 42.69 & 4.41 & 0.05 \\
\hline G & -19.830 & 2 & 43.70 & 5.49 & 0.03 \\
\hline$E+G+W$ & -18.156 & 4 & 44.70 & 6.42 & 0.02 \\
\hline $\mathrm{G}+\mathrm{W}$ & -19.484 & 3 & 45.20 & 6.92 & 0.02 \\
\hline$A+W$ & -23.961 & 3 & 54.15 & 15.87 & 0.01 \\
\hline A & -25.234 & 2 & 54.58 & 16.30 & 0.00 \\
\hline $\mathrm{E}+\mathrm{A}+\mathrm{W}$ & -23.945 & 4 & 56.26 & 17.99 & 0.00 \\
\hline $\mathrm{E}+\mathrm{A}$ & -25.207 & 3 & 56.64 & 18.38 & 0.00 \\
\hline W & -30.081 & 2 & 64.28 & 25.99 & 0.00 \\
\hline $\mathrm{E}$ & -31.038 & 2 & 66.19 & 27.91 & 0.00 \\
\hline$E+W$ & -30.022 & 3 & 66.27 & 27.99 & 0.00 \\
\hline
\end{tabular}

large rock structures in the foothills west of Boulder and Fort Collins. All bats that could be seen were roosting within clusters of other bats. The smallest cluster observed consisted of 4 bats roosting in a crevice in a large boulder. All other clusters were estimated to consist of between 10 and 30 bats. These observations are consistent with those of this species' use of rock structures in other parts of the western United States (Bogan et al. 1998, Cryan et al. 2001, Lacki and Baker 2007). The largest maternity colonies of fringed myotis we observed were in abandoned mines, and over 100 individuals of this species were observed in 2 abandoned mines in southeastern Colorado and northeastern New Mexico.
The maternity roosts located in rock structures along the Colorado Front Range in Boulder and Larimer Counties tended to be located on landscape features with steeper grades and easterly, southerly, and southwesterly aspects. Rock structures on hillsides with southerly aspects and steeper grades receive greater direct solar radiation in midsummer at the latitudes in our study area (Larson et al. 2000). This increased solar radiation could result in roost microclimates that are more conducive to growth and development of prenatal and postnatal young, and such conditions might result in greater reproductive success (Hayes 2011).

In this data set, the mean distance to a permanent water source for fringed myotis 
TABLE 5. Cumulative $\mathrm{AIC}_{c}$ weight $\left(w_{+}\right)$for each landscape and roost-site variable used in the balanced model comparisons using landscape data collected at 109 sites (9 fringed myotis [Myotis thysanodes] maternity sites and 100 randomly selected points) and roost-site data collected at fringed myotis maternity roosts and randomly selected potential roost sites $(9$ maternity roosts and 18 randomly selected potential roosts). A cumulative $\mathrm{AIC}_{c}$ weight of 1.00 indicates the highest possible weight, and higher weights suggest that the variable is more important, given the variables and data used.

\begin{tabular}{lc}
\hline & $w_{+}$ \\
\hline Landscape variables & \\
Grade $(\%)$ & 1.00 \\
Aspect & 0.89 \\
Elevation $(\mathrm{m})$ & 0.37 \\
Proximity to water $(\mathrm{m})$ & 0.27 \\
Roost-site variables & \\
Estimated roost volume $\left(\mathrm{m}^{3}\right)$ & 0.74 \\
Average roost temperature $\left({ }^{\circ} \mathrm{C}\right)$ & 0.56 \\
Relative humidity $(\% \mathrm{RH})$ & 0.47 \\
\hline
\end{tabular}

maternity roosts was $546 \mathrm{~m}(95 \%$ CI $274-817$ $\mathrm{m})$, whereas the mean distance to water for randomly selected sites was $988 \mathrm{~m}$ (95\% CI 744-1202 m). Although the distance to a permanent water resource (proximity to water) had a low cumulative $\mathrm{AIC}_{c}$ weight, and there is overlap between the $95 \%$ confidence intervals for proximity to water for randomly selected potential roosts and fringed myotis maternity roosts, it is possible that this species chooses maternity roosts that tend to be, but are not significantly (in the formal statistical sense), closer to permanent surface water resources. Water resources are important to insectivorous bats living in arid environments, and some species experience high levels of evaporative and respiratory water loss (Studier and O'Farrell 1976, Adams and Thibault 2006, Adams and Hayes 2008, Adams 2010). Readily available water is important to bats in arid environments. Adams and Thibault (2006) found that the maternity roosts of Myotis species in their study area, including fringed myotis, appeared to be clustered near reliable water resources. Adams and Hayes (2008) found that lactating female fringed myotis visited an artificial water resource 13 times more often to drink water than nonreproductive females. Thus, it would be reasonable to continue consideration of proximity to water in other maternity roost selection studies, including studies involving fringed myotis. It is possible that in our study area water is generally more available than in other, more arid, parts of the fringed myotis range in Colorado and elsewhere in this species' range.

The roost-site analysis suggests that the average temperature and relative humidity inside maternity roosts is not statistically different from the average temperature and relative humidity in randomly selected potential roosts on the landscape. This is a surprising result. Data logger results indicate that fringed myotis maternity roosts on average are not characterized by higher and more stable temperatures, or higher average relative humidity, than randomly selected potential roosts that are available in the same area. However, we suspect that these variables may be important in differentiating the highestquality roosts from randomly selected sites. The largest maternity colony of fringed myotis identified in this study was located in an abandoned mine in southeastern Colorado. This fringed myotis maternity site had the most stable temperature $\left(\bar{x}=14.5{ }^{\circ} \mathrm{C}, \sigma=0.3\right)$ of all sites evaluated in this study. This site also had the lowest variability in relative humidity $(\bar{x}=87.7 \% \mathrm{RH}, \sigma=10.9)$, except for one randomly selected north-facing rock crevice. The field survey evidence suggests that maternity colonies of fringed myotis have likely used this abandoned mine for over 30 years (Ellinwood 1978, Armstrong et al. 1994, Navo personal communication, Hayes and Bonewell unpublished data). Alternatively, a maternity site of fringed myotis located in an abandoned cabin, which has been used for a number of years by this species, had the most variable temperature $\left(\bar{x}=24.3^{\circ} \mathrm{C}, \sigma=17.6\right)$ and relative humidity $(\bar{x}=50.2 \% \mathrm{RH}, \sigma=34.6)$ of all sites evaluated. We believe this variability is in part due to where we placed the data loggers inside the cabin. We placed 2 data loggers in the areas near where bats were roosting in the south part of the cabin attic near a loft door. At the time we observed bats in this roost, the internal temperature of the roost near the bats was approximately $25{ }^{\circ} \mathrm{C}$. Large congregations of bats can create more stable microclimates within roost sites (Studier 1970). However, it is clear from the data collected by the data loggers that the temperature and relative humidity at this site vary dramatically. It seems likely that the reproductively active females that use this roost move among several sites inside the cabin, and perhaps elsewhere, to take advantage of 
TABLE 6. Unconditional parameter estimate $\left(\widetilde{\bar{\beta}_{i}}\right)$, unconditional standard error (SE), and associated $95 \%$ confidence interval for the 4 landscape variables used in the balanced model comparison using data collected at 109 sites $(9$ fringed myotis [Myotis thysanodes] maternity sites and 100 randomly selected points) and 3 roost-site variables used (9 maternity roosts and 18 randomly selected potential roosts). Temp $\left({ }^{\circ} \mathrm{C}\right)$ is mean temperature and Humidity $(\% \mathrm{RH})$ is mean relative humidity.

\begin{tabular}{lrrrr}
\hline & & & \multicolumn{2}{c}{$95 \%$ Confidence limits } \\
\cline { 4 - 4 } & $\widetilde{\bar{\beta}}_{i}$ & SE & Lower & Upper \\
\hline Landscape variables & & & & -14.3558 \\
$\quad$ Constant (intercept) & -10.5654 & 1.9339 & 0.0840 & -6.7750 \\
Grade $(\%)$ & 0.0896 & 0.0029 & 4.6508 & 0.0952 \\
Aspect & 7.9200 & 1.6679 & 0.0000 & 0.0000 \\
Elevation $(\mathrm{m})$ & 0.0000 & 0.0000 & -0.0003 & 0.0001 \\
Proximity to water $(\mathrm{m})$ & -0.0001 & 0.0001 & -0.1947 & 0.3872 \\
Roost-site variables & & & -0.0593 & 0.0436 \\
Temp $\left({ }^{\circ} \mathrm{C}\right)$ & 0.0963 & 0.1485 & -0.0119 & 0.0343 \\
Humidity $(\% \mathrm{RH})$ & -0.0079 & 0.0262 & & \\
Roost volume $\left(\mathrm{m}^{3}\right)$ & 0.0112 & 0.0118 & & \\
\hline
\end{tabular}

TABLE 7. Log-likelihood, number of parameters $(K)$, Akaike's information criterion adjusted for small sample size $\left(\mathrm{AIC}_{c}\right), \mathrm{AIC}_{c}$ difference $\left(\Delta_{i}\right)$, and $\mathrm{AIC}_{c}$ weight $\left(w_{i}\right)$ for each roost-site model used in the balanced model comparison using data collected at fringed myotis (Myotis thysanodes) maternity roosts and randomly selected potential roost sites $(9$ maternity roosts and 18 randomly selected potential roosts). Temp $=$ average roost temperature $\left({ }^{\circ} \mathrm{C}\right)$; Humidity $=$ relative humidity $(\% \mathrm{RH})$; Volume = estimated roost volume $\left(\mathrm{m}^{3}\right)$. The model "Temp + Humidity + Volume," for example, includes all 3 variables. Higher $\mathrm{AIC}_{c}$ weights indicate more support for the model, given the variables and data used.

\begin{tabular}{lccccc}
\hline Model & Log likelihood & $K$ & $\mathrm{AIC}_{c}$ & $\Delta_{i}$ & $w_{i}$ \\
\hline Volume & -12.863 & 2 & 30.21 & 0.00 & 0.30 \\
Temp + Humidity & -11.758 & 3 & 30.52 & 0.31 & 0.26 \\
Temp + Volume & -11.861 & 3 & 30.72 & 0.52 & 0.23 \\
Humidity + Volume & -12.336 & 3 & 31.67 & 1.47 & 0.14 \\
Temp + Humidity + Volume & -11.758 & 4 & 33.26 & 3.05 & 0.06 \\
Temp & -17.179 & 2 & 38.84 & 8.63 & 0.00 \\
Humidity & -17.449 & 2 & 39.38 & 9.17 & 0.00 \\
\hline
\end{tabular}

varying temperatures in different parts of the cabin.

Several randomly selected tree snags that were used as potential roost sites in this study had temperature and relative humidity profiles that appeared to offer potentially suitable microclimates for fringed myotis. Although these snags generally exhibited moderately variable temperature and relative humidity profiles, they exhibited short periods of stable temperatures with high humidity. For example, the temperature and humidity profile of one snag was similar to the abandoned mine roost conditions described above, whereas the abandoned cabin roost was much more variable in temperature and humidity.

This research tentatively supports the hypothesis that fringed myotis in Colorado preferentially select roost sites in rock substrates compared to tree snags. This hypothesis proposes that where there is a suite of potential roost sites available, including rock crevices and tree snags, fringed myotis maternity roosts will tend to be found in rock substrates more frequently than in other roost types. We did not have difficulty finding tree snags during this project, and there appear to be abundant snags available for roosting in most areas where we conducted fieldwork. However, our research group has yet to radio-track a Myotis of any species to a tree snag in the midelevation forests along the Colorado Front Range. These results do not, however, suggest that maternal fringed myotis use rock crevices as roost sites because the Front Range lacks adequate roosting opportunities in ponderosa pine and Douglas-fir snags; on the contrary, these results suggest that rock formations may be preferred by this species to the available tree snags along the Front Range. Our working hypothesis is that fringed myotis likely do use tree snags when alternative roosts that provide more consistent microclimates and that are more permanent features on the landscape (such as 
rock crevices, caves, and abandoned mines) are not available. Along the Colorado Front Range, there appears to be plentiful roosting resources available in rock features. Tree snags, although abundant in our study area, are ephemeral roosting resources and do not persist for long periods on the landscape (Lewis 1995). On the other hand, abandoned mines, caves, and refugia in rock features tend to have more permanence, and may be preferred as maternity roosting resources, when available.

It is possible that reproductive female fringed myotis that use roost sites that are characterized by lower thermal entropy may experience higher average reproductive rates and average pup survival rates. Thermal entropy, as we use it here, is a measure of the variability of the temperature in a site, with low thermal entropy values indicating sites that have more stable internal temperatures. It is also possible that female fringed myotis may have higher fidelity to maternity roosts that exhibit lower thermal entropy. To evaluate this hypothesis, we calculated a post hoc measure of thermal entropy for each fringed myotis maternity roost and randomly selected potential roost used in this study. For the thermal entropy measure, we calculated the base $e$ information entropy applied to all temperature measurements collected for each site from 1 June to 15 August using Mathematica ${ }^{\mathrm{TM}}$ 8.0 (Wolfram Research, Champaign, IL). The average thermal entropy measure $(S)$ for maternity roosts was $3.15(\sigma=0.37,95 \%$ CI $2.43-3.87$ ), whereas the average for randomly selected potential roost sites was $3.63(\sigma=$ $0.08,95 \%$ CI 3.46-3.79). Though the 95\% confidence intervals overlapped for known maternity roosts and randomly selected potential roosts, the 2 large fringed myotis maternity colonies in this data set that had high site fidelity had the 2 lowest thermal entropy values of all the sites evaluated (abandoned copper mine $1, S=0.99$; abandoned copper mine $2, S=2.00)$. We propose that it may be useful to include a measure of thermal entropy in future roost-site selection studies. It is possible that roosting in structures with stable temperatures provides thermally predictable environments that require lower metabolic costs to maintain basal metabolic rates. In such environments, reproductive females may have more metabolic energy available to devote to growth and development of pups. In turn, pups may also grow more rapidly and reach volancy earlier than if they developed in more variable thermal environments. We predict that adult females using maternity roosts with low thermal entropy and average temperatures near or within the species' thermal neutral zone will have higher fecundity, and their pups will have higher first-year survival, compared to adult females using sites with higher thermal entropy.

Of the female fringed myotis tracked to maternity roosts, all but 2 bats stayed in the same roost location until the radio failed. The 2 females that moved each moved only once to a nearby roost within $500 \mathrm{~m}$ of the original roost. These data suggest that fringed myotis in our study area have high fidelity to maternity roost locations, once maternity roosts are established. Maternity colonies of fringed myotis in our study area have been observed returning to the same roost in multiple years. Field surveys suggest that maternity colonies of fringed myotis have likely used the same abandoned mines in southeastern Colorado and northeastern New Mexico for over 30 years (Hayes 2011). Along the Colorado Front Range, it appears that individuals of this species establish maternity roosts in permanent rock structures and return to these rock structures (or a cluster of nearby structures) year after year. We conclude that maternal fringed myotis females have higher maternity roost site fidelity when using sites that have relatively stable microclimates and high permanence.

In Colorado, maternity roosts of fringed myotis are rare, and the identification and protection of these roosts can require significant investments of time and resources, and may require many years of effort. For example, since 1991, the Colorado Bats/Inactive Mines Project has conducted over 3000 capture and internal surveys at abandoned mines throughout Colorado (K. Navo personal communication, Hayes 2012). Similarly, for over 20 years, one of us (RAA) has been capturing and radiotracking forest bats in the foothills west of Boulder, in cooperation with the City and County of Boulder, Colorado. Yet, after over 2 decades of bat research by these projects, only 14 fringed myotis maternity roosts have been identified in Colorado. Once maternity roosts are identified, there are several options available to wildlife and resource managers. Caves 
and abandoned mines can be protected from human disturbance by installing bat-compatible gates (e.g., Navo 2001, Navo and Krabacher 2005). Seasonal closures can also be implemented at and near maternity sites in areas that are visited regularly by humans. For example, the Boulder Open Space and Mountain Parks Department (OSMP) has implemented an annual closure from 1 April to 1 September to protect a fringed myotis maternity colony that uses the east face of Der Zerkle, a popular rock-climbing route. This seasonal closure required OSMP to obtain approval for the closure from the Boulder City Council. Therefore, identification and protection of fringed myotis maternity roosts, and those of other bat species of conservation concern, can take many years and the coordinated efforts of biologists, rangers, land and resource managers, and politicians. Additionally, as more maternity roosts are identified, more information will be available for further statistical analyses of roosts occupied by reproductive female fringed myotis. We emphasize that, given the relatively small sample size of known maternity roosts in Colorado $(n=14)$, these results should be interpreted only as working hypotheses of maternity roost selection by this species.

Improved understanding of the use of maternity roost sites in Colorado will help biologists and managers protect fringed myotis populations in the Southern Rocky Mountains. Reproductive fringed myotis females use a variety of roosting resources as maternity sites, including abandoned mines, cabins, and rock crevices. We did not find evidence of this species using tree snags as roosting habitat. Management actions intended to protect fringed myotis maternity colonies in Colorado might include working with public land management agencies and private landowners to identify and protect key roost and water resources used by this species; minimizing human disturbance and predation at maternity roosts, for example by installing bat gates where appropriate; taking action to prevent the spread of bat diseases, such as white-nose syndrome, into maternity and other nearby winter roost sites; protecting, and when appropriate, enhancing foraging habitat associated with forest and riparian areas near key roost sites; and minimizing or preventing disruptive human activity, such as recreational rock climbing and noisy forest treatment procedures near maternity sites during the late spring and summer months.

\section{ACKNOWLEDGMENTS}

The Colorado Wildlife Conservation Grant program, administered cooperatively by Colorado Parks and Wildlife and U.S. Fish and Wildlife Service, was generous in supporting the field research detailed in this paper. The Boulder County Parks \& Open Spaces department also was generous in funding, support, and access to their properties. Several municipalities and private landowners were helpful in allowing access to their properties. M.A. Hayes was supported over several years by the University of Northern Colorado (UNC) School of Biological Sciences. Members of the UNC Chiropteran Research Laboratory, including E. Snode, R. Carter, B. Bales, K. Craven, and J. Kiser, provided insightful advice and field assistance, and there would still be data loggers in one of the Poudre Canyon maternity roosts without the rappelling expertise of M. Willey and J. Shaw. K. Navo and L. Bonewell provided information and expertise about use of abandoned mines by fringed myotis in Colorado.

\section{Literature Cited}

AdAms, R.A. 2003. Bats of the Rocky Mountain West: natural history, ecology, and conservation. University Press of Colorado, Boulder, CO.

ADAms, R.A. 2010. Bat reproduction declines when conditions mimic climate change projections for western North America. Ecology 91:2437-2445.

ADAMS, R.A., AND M.A. HAYES. 2008. Water availability and successful lactation by bats as related to climate change in arid regions of western North America. Journal of Animal Ecology 77:1115-1121.

Adams, R.A., and K.M. Thibault. 2006. Temporal partitioning by bats at water holes. Journal of Zoology, London 270:466-472.

Aldridge, H.D.J.N., and R.M. Brigham. 1988. Load carrying and maneuverability in an insectivorous bat: a test of the $5 \%$ rule of radio-telemetry. Journal of Mammalogy 69:379-382.

Amelon, S.K., D.C. Dalton, J.J. Millspaugh, and S.A. WOLF. 2009. Radiotelemetry: techniques and analysis. Pages 57-77 in T.H. Kunz and S. Parsons, editors, Ecology and behavioral methods for the study of bats. 2nd edition. Johns Hopkins University Press, Baltimore, MD.

Armstrong, D.M., R.A. Adams, and J. Freeman. 1994. Distribution and ecology of bats of Colorado. Natural History Inventory of Colorado, No. 15: $1-83$.

Armstrong, D.M., C.A. Meaney, and J.P. Fitzgerald. 2011. Mammals of Colorado. 2nd edition. Denver 
Museum of Natural History and University Press of Colorado, Niwot, CO.

ArNell, N.W. 2004. Climate change and global water resources: SRES emissions and socio-economic scenarios. Global Environmental Change 14:31-52.

Auble, G.T., M. Wondzell, and C. Talbert. 2009. Decision support system for evaluation of Gunnison River flow regimes with respect to resources of the Black Canyon of the Gunnison National Park. Open file report 2009-1126, U.S. Geological Survey, Gunnison, $\mathrm{CO}$.

BJörk, R.G., AND U. MolaU. 2007. Ecology of alpine snowbeds and the impact of global change. Arctic, Antarctic, and Alpine Research 39:34-43.

Bogan, M.A., T.J. O’Shea, P.M. Cryan, A.M. DitTo, W.H. Schaedla, E.W. Valdez, K.T. Castle, and L. ElliSON. 1998. A study of bat populations at Los Alamos National Laboratory and Bandelier National Monument, Jemez Mountains, New Mexico. LA-UR-982418, Los Alamos National Laboratory, Los Alamos, NM.

Brunet-Rossinni, A.K., AND G.S. Wilkinson. 2009. Methods for age estimation and the study of senescence in bats. Pages 315-325 in T.H. Kunz and S. Parsons, editors, Ecology and behavioral methods for the study of bats. 2nd edition. Johns Hopkins University Press, Baltimore, MD.

Burnham, K.P., AND D.R. ANDERSON. 2002. Model selection and multimodel inference: a practical informationtheoretic approach. 2nd edition. Springer, NY.

CADE, B.S. 2015. Model averaging and muddled multimodel inference. Ecology 96:2370-2382.

Chapman, S.S., G.E. Griffith, J.M. Omernick, A.B. Price, J. Freeouf, AND D.L. Schrupp. 2006. Ecoregions of Colorado. U.S. Geological Survey, Reston, VA.

Christensen, N., and D.P. Lettenmaier. 2006. A multimodel ensemble approach to assessment of climate change impacts on the hydrology and water resources of the Colorado River Basin. Hydrology and Earth System Science Discussions 3:3727-3770.

Chung-MacCoubrey, A.L. 2003. Monitoring long-term use of trees by bats in pinyon-juniper woodlands of New Mexico. Wildlife Society Bulletin 31:73-79.

Chung-MacCoubrey, A.L. 2005. Use of pinyon-juniper woodlands by bats in New Mexico. Forest Ecology and Management 204:209-220.

[CDOW] Colorado Division of Wildlife. 2005. Colorado's Comprehensive Wildlife Conservation Strategy: including references to wildlife action plans. Colorado Division of Wildlife, Denver, CO.

Cryan, P.M., M.A. Bogan, and G.M. Yanega. 2001. Roosting habits of four bat species in the Black Hills of South Dakota. Acta Chiropterologica 3: 43-52.

Dalquest, W.W., F.B. Stangl, and J.K. Jones Jr. 1990. Mammalian zoogeography of a Rocky MountainGreat Plains interface in New Mexico, Oklahoma, and Texas. Special Publication Number 34, Texas Tech University Press, Lubbock, TX.

ELLinwood, R.R. 1978. A survey of bats in southeast Colorado. Master's thesis, University of Northern Colorado, Greeley, CO.

Ellison, L.E., M.B. Wunder, C.A. Jones, C. Mosch, K.W. Navo, K. Peckham, J.E. Burghardt, J. Annear, R. West, J. Seimers, et al. 2003. Colorado Bat Conservation Plan. Colorado Committee of the Western Bat Working Group.
Findley, J.S., A.H. HarRis, D.E. Wilson, and C. Jones. 1975. Mammals of New Mexico. University of New Mexico Press, Albuquerque, NM.

Grimm, N.B., D. Foster, P. Groffman, J.M. Grove, C.S. Hopkinson, K.J. Nadelhoffer, D.E. Pataki, and D.P.C. Peters. 2008. The changing landscape: ecosystem responses to urbanization and pollution across climatic and societal gradients. Frontiers in Ecology and Environment 6:264-272.

Hayes, M.A. 2011. An analysis of fringed myotis (Myotis thysanodes) with a focus on Colorado distribution, maternity roost selection, and preliminary modeling of population dynamics. Doctoral dissertation, University of Northern Colorado, Greeley, CO.

Hayes, M.A. 2012. Bats, mines, and citizen science in the Rockies: volunteers make a difference in Colorado. Bats 30:10-11.

Hayes, M.A., AND R.A. ADAms. 2014. Geographic and elevational distribution of fringed myotis (Myotis thysanodes) in Colorado. Western North American Naturalist 74:446-455.

KANG, B., AND J.A. RAmíREZ. 2007. Response of streamflow to weather variability under climate change in the Colorado Rockies. Journal of Hydrologic Engineering 12:63-72.

Keating, K.A., And S. Cherry. 2004. Use and interpretation of logistic regression in habitat-selection studies. Journal of Wildlife Management 68:774-789.

LACKI, M.J., AND M.D. BAKER. 2007. Day roosts of female fringed myotis (Myotis thysanodes) in xeric forests of the Pacific Northwest. Journal of Mammalogy 88: 967-973.

Larson, D.W., U. Matthes, and P.E. Kelly. 2000. Cliff ecology: patterns and process in cliff ecosystems. Cambridge University Press, Cambridge, United Kingdom. dx.doi.org/10.1017/CBO9780511525582

LEWIS, S.E. 1995. Roost fidelity of bats: a review. Journal of Mammalogy 76:481-496.

Magle, S.B., D.M. Theobald, and K.R. Crooks. 2009. A comparison of metrics predicting landscape connectivity for a highly interactive species along an urban gradient in Colorado, USA. Landscape Ecology 24: 267-280.

NAvO, K.W. 2001. The survey and evaluation of abandoned mines for bat roosts in the West: guidelines for natural resource managers. Proccedings of the Denver Museum of Nature and Science 4(2):1-12.

Navo, K.W., C.L. Knapp, and J. Sheppard. 1991. Colorado's Bats/Inactive Mines Project. Bat Research News 32:81.

Navo, K.W., and P. Krabacher. 2005. The use of gates at abandoned mines in Colorado. Bat Research News 46:1-8.

Neubaum, D.J., M.A. Neubaum, L.E. Ellison, and T.J. O'SHEA. 2005. Survival and condition of big brown bats (Eptesicus fuscus) after radiotagging. Journal of Mammalogy 86:95-98.

O'Farrell, M.J., and E.H. Studier. 1980. Myotis thysanodes. Mammalian Species 137:1-5.

O'Shea, T.J., M.A. Bogan, and L.E. Ellison. 2003. Monitoring trends in bat populations of the United States and territories: status of the science and recommendations for the future. Wildlife Society Bulletin 31: 16-29.

Rabe, M.J., T.E. Morrell, H. Green, J. De Vos Jr., And C.R. Miller. 1998. Characteristics of ponderosa pine snag roosts used by reproductive bats in 
northern Arizona. Journal of Wildlife Management 62:612-621.

RaCEY, P.A. 2009. Reproductive assessment in bats. Pages 249-264 in T.H. Kunz and S. Parsons, editors, Ecology and behavioral methods for the study of bats. 2nd edition. Johns Hopkins University Press, Baltimore, MD.

Ray, A.J., J.J. Barsugli, K.B. Averyt, K. Wolter, M. Hoerling, N. Doesken, B. Udall, and R.S. Webb. 2008. Climate change in Colorado: a synthesis to support water resources management and adaptation. A report by the Western Water Assessment for the Colorado Water Conservation Board, Denver, CO. 52 pp.

Saunders, S., C. Montgomery, T. Easley, and T. Spencer. 2008. Hotter and drier: the West's changed climate. The Rocky Mountain Climate Organization and the Natural Resources Defense Council.

Sikes, R.S., W.L. Gannon, and the Animal Care and Use Committee of the American Society of Mammalogists. 2011. Guidelines of the American Society of Mammalogists for the use of wild animals in research. Journal of Mammalogy 92:235-253.

StUdier, E.H. 1968. Fringe-tailed bat in northeastern New Mexico. Southwestern Naturalist 13:362.

Studier, E.H. 1970. Evaporative water loss in bats. Comparative Biochemistry and Physiology (A) 35: 935-943.

Studier, E.H., and M.J. O’Farrell. 1976. Biology of Myotis thysanodes and M. lucifugus (Chiroptera: Vespertilionidae)_III. Metabolism, heart rate, breath- ing rate, evaporative water loss and general energetics. Comparative Biochemistry and Physiology 54:423-432.

[USFWS] United States Fish and Wildlife Service. 1994. 50 CFR Part 17. Endangered and threatened wildlife and plants; notice of final decision on identification of candidates for listing as endangered or threatened. Federal Register 61(235):64481-64485.

[USFWS] United States Fish and Wildlife Service. 1996. Endangered and threatened wildlife and plants: notice of final decision on identification of candidates for listing as endangered or threatened. 50 CFR Part 17. Federal Register 61 (235):64481-64485.

USDA Forest Service. 2006. Forest Service Manual Rocky Mountain Region (Region 2), Denver, Colorado, FSM 2600_-Wildlife, fish, and sensitive plant habitat management, Chapter 2670-Threatened, endangered, and sensitive plants and animals. Supplement No. 2600-2006-1, 3 May 2006, Denver, CO.

Weller, T.J., AND C.J. Zabel. 2001. Characteristics of fringed myotis day roosts in northern California. Journal of Wildlife Management 65:489-497.

Western Bat Working Group. 1998. Western bat species: regional priority matrix. Western Bat Working Group Workshop, Reno, NV.

Western Regional Climate Center. 2010. Colorado climate summaries. [Accessed 21 December 2010]. http://wrcc.dri.edu/summary/climsmco.html

Received 8 March 2015 Accepted 11 August 2015 